\title{
UJI AKTIVITAS PENINGKAT DAYA INGAT FRAKSI ETIL ASETAT EKSTRAK ETANOL BUAH KEMUKUS (Piper cubeba L. f) PADA MENCIT JANTAN GALUR BALB/C DENGAN METODE RADIAL ARM MAZE (RAM)
}

\author{
Junvidya Heroweti $^{1 *}$, Yance Anas $^{1)}$, Idress Muhammed Hama ${ }^{2)}$ \\ ${ }^{1)}$ Bagian Farmakologi dan Farmasi Klinik Fakultas Farmasi Universitas Wahid Hasyim \\ ${ }^{2)}$ Program Studi S1 Farmasi Fakultas Farmasi Universitas Wahid Hasyim \\ Jl. Menoreh Tengah X/22 Sampangan, Semarang 50236 \\ *Email: junvidyaheroweti@unwahas.ac.id
}

\section{INTISARI}

Neurodegenerative sering dikaitkan dengan proses penuaan/aging. Proses penuaan akan mempengaruhi penurunan sel syaraf khususnya sel syaraf otak. Telah dilakukan penelitian aktivitas fraksi etil asetat ekstrak etanol (FEAEE) buah kemukus sebagai peningkat daya ingat dengan metode Morris water maze. Salah satu kekurangan metode Morris water maze (MWM) adalah menyebabkan stres pada hewan uji, sehingga berpengaruh terhdap daya ingatnya. Penelitian bertujuan untuk mengetahui aktivitas peningkat daya ingat FEAEE buah kemukus dengan metode radial arm maze.

Penelitian ini dilakukan dengan rancangan pre and post test matched control group design,menggunakan 25 ekor mencit jantan galur Balb/c terbagi dalam 5 kelompok. Kelompok 1(kontrol negatif) diberi larutan CMC Na 1\% 17,5 mg/mL. Kelompok 2, 3, 4, 5 diberi FEAEE buah kemukus dengan dosis berturut-turut 63, 126, 252, dan $504 \mathrm{mg} / \mathrm{kgBB}$. Pemberian bahan uji secara per oral selama 21 hari. Pengamatan dilakukan terhadap frekuensi mencit melewati platform dengan benar dan salah dan menghitung skor memori menggunakan metode radial arm maze $(R A M)$. Perbedaan skor memori diuji dengan uji Mann Whitney. Hasil penelitian menunjukkan bahwa FEAEE buah kemukus mempunyai aktivitas peningkat daya ingat. Aktivitas daya ingat ditunjukkan pada dosis 63 dan $252 \mathrm{mg} / \mathrm{kgBB}$.

Kata kunci: Buah kemukus (Piper cubeba, L. f), fraksi etil asetat, skor memori, radial arm maze

\section{ABSTRACT}

Neurodegenerative is often associated with aging. The aging process will affect the decrease in nerve cells, especially brain nerve cells. Ethyl acetate fraction of kemukus fruit ethanol extract (FEAEE) of kemukus fruit has been investigated as a memory enhancer with the Morris water maze (MWM) method. One of the shortcomings of the Morris water maze method is that it causes stress in test animals, thus affecting their memory. This study aims to determine the memory enhancing activity of FEAEE of kemukus fruit with the radial arm maze method

This research is an experimental study with pre and posttest matched control group design using 25 male mice, Balb/c strains divided into 5 groups. Mice group 1 as a negative control group were given a $1 \%$ CMC Na solution of $17.5 \mathrm{mg} / \mathrm{mL}$. Group mice 2 - 5 were given FEAEE of kemukus fruit with doses of 63, 126, 252, and $504 \mathrm{mg} / \mathrm{kgBB}$, respectively. Test material is given orally for 21 days. Observations were made on the frequency of mice passing the platform correctly and incorrectly and calculating memory scores using the radial arm maze (RAM) method. Differences in memory scores were analyzed by the Mann Whitney test. The results showed that 
FEAEE steamed fruit has memory enhancing activity. Memory activity was indicated at doses of 63 and $252 \mathrm{mg} / \mathrm{kg}$.

Keywords: steamed fruit (Piper cubeba, L. f), ethyl acetate fraction, memory score, radial arm maze

"Corresponding author:

Junvidya Heroweti

Bagian Farmakologi dan Farmasi Klinik Fakultas Farmasi Universitas Wahid Hasyim

Jl.Menoreh Tengah X/22 Sampangan-Semarang 50236

Email: junvidyaheroweti@unwahas.ac.id

\section{PENDAHULUAN}

Penyakit neurodegenerative sering dikaitkan dengan proses penuaan/aging. Proses penuaan akan mempengaruhi penurunan sel syaraf khususnya sel syaraf otak. Normalnya, sel yang masih muda memiliki kemampuan memperbaharui diri, mempertahankan struktur ,fungsi, dan mampu memperbaiki kerusakan. Salah satu akibat menurunnya sel syaraf adalah menurunnya kualitas memori, atau pembelajaran, serta meningkatnya stress oksidatif. Tidak berimbangnya produksi radikal bebas dengan antioksidan menyebabkan terjadinya stres oksidatif yang berperan dalam rusaknya neuron, sehingga terjadi demensia (Pham-Huy dkk., 2008). Menurut National Institue on Aging (2010), terdapat banyak penyebab daya ingat seseorang menurun bahkan kehilangan ingatan, diantaranya adalah reaksi buruk terhadap obat-obatan tertentu, depresi, tidak mengonsumsi makanan sehat yang cukup, konsumsi alkohol, terdapat bekuan darah atau tumor di otak, cidera kepala, serta gangguan tiroid, ginjal, dan hati. Selain itu, penyakit neurodegeneratif yang menyebabkan penurunan kualitas memori diantaranya ialah Alzheimer, demensia vaskuler, demensia dengan body lewy, dan demensia frontotemporal (Prince dkk., 2014).

Kandungan flavonoid pada buah kemukus, selain sebagai antioksidan, juga dapat meningkatkan fungsi kognitif melalui aksinya sebagai neuroprotektif, meningkatkan fungsi neuron, dan menstimulasi neurogenesis. Flavonoid mempunyai kemampuan menembus sawar darah otak dan terdeteksi pada otak tikus di bagian pembelajaran dan daya ingat, sesaat setelah diberikan secara per oral. Flavonoid mencegah penurunan daya ingat yang berhubungan dengan penuaan dan juga proses neurodegeneratif. Mekanisme flavonoid dalam mengurangi penurunan kognitif diperkirakan melalui kemampuannya berinteraksi dengan jalur persinyalan neuron intraseluler yang memediasi neurodegenerasi dan neuroinflamasi (Macready dkk., 2009).

Long term potentiation (LTP) adalah peningkatan respon potensial post-sinaptik, bersifat menetap dan terbentuk secara cepat, setelah perangsangan di neuron sipnatik (Ganong, 2002). LTP merupakan salah satu dasar mekanisme seluler utama dalam pembelajaran dan memori. Prinsip dari LTP adalah jika sinyal yang diterima pre sinap kuat dan berulang, maka koneksi di pre sinap dan post sinap akan menguat. Informasi dalam bentuk sinyal diterima oleh kortek otak, kemudian akan ditransmisikan ke hipokamus. Sinyal akan menyebabkan terjadinya pelepasan glutamin pada pre sinap. Reseptor AMPA dan reseptor NMDA adalah reseptor pada post sinap. Glutamin yang dilepaskan oleh pre sinap akan berikatan dengan reseptor AMPA dan reseptor NMDA. Berikatannya glutamin dengan reseptor AMPA mengakibatkan membukanya celah pada reseptor AMPA sehingga ion $\mathrm{Na}^{+}$masuk ke dalam post sinap. Banyaknya $\mathrm{Na}^{+}$yang masuk post sinap bergantung oleh ikatan glutamin dengan reseptor AMPA. ion $\mathrm{Ca}^{2+}$ akan mengaktivasi CaMKII. Fase LTP lebih lanjut adalah sintesis cyclic adenosine monophosphate response element-binding protein (CREB) (Sherwood, 2013). CREB berperan dalam penguatan memori jangka pendek agar menjadi memori jangka panjang melalui proses LTP (Kida, 2012).

Salah satu metode yang dapat digunakan untuk mengetahui memori spasial hewan uji adalah Radial Arm Maze (RAM). RAM merupakan alat untuk mengetahui memori spasial pada hewan uji dengan cara membuat hewan berenang untuk menemukan platform/labirin (Prichett dan Mulder, 2003). Memori spasial merupakan kemampuan untuk mengingat suatu lokasi subyek, ruangan, tempat, atau arah (Chalfonte dkk., 1996; Guyton \& Hall, 2001; Pinel, 2009). Dalam perlakuan ini 
memori spasial mencit merupahan hasil daya ingat mencit menemukan platform dari titik awal hingga menemukan platform dalam sumur Radial Arm Maze (RAM) selama tiga menit. Kebenaran menemukan platform dan semakin cepat waktu yang dipakai untuk menemukan platform, menunjukkan ingatan spasial semakin baik.

Fraksi etil asetat ekstrak etanol (FEAEE) buah kemukus yang mempunyai potensi yang tinggi sebagai peningkat daya ingat memberi peluang dikembangkannya penelitian ini. Pengembangan dapat dilakukan dengan cara menggunakan hewan uji yang dibuat mengalami penurunan daya ingat.

\section{METODE PENELITIAN \\ Bahan Penelitian}

Bahan penelitian adalah buah kemukus yang diperoleh dari Balai Besar Penelitian dan Pengembangan Tanaman Obat dan Obat Tradisional (B2P2POOT) Tawangmangu, Karanganyar, Jawa Tengah, etanol 70\%, etil asetat, CMC-Na, aquadest dan pelet.

\section{Alat Penelitian}

Seperangkat alat untuk ekstraksi, seperangkat alat uji radial arm maze (lokal), spuit oral, alat gelas, corong pisah, timbangan hewan.

\section{Jalannya Penelitian}

\section{Pembuatan fraksi etil asetat ekstrak etanol buah kemukus}

Fraksinasi ekstrak etanol buah kemukus dengan pelarut campuran air-etanol $70 \%$ dengan perbandingan 9:1 dalam corong pisah kemudian digojog hingga campuran memisah menjadi dua lapisan yaitu lapisan larutan ekstrak etanol buah kemukus dan lapisan etil asetat. Fraksi etil asetat yang terkumpul diuapkan dengan rotary evaporator pada suhu $55^{\circ} \mathrm{C}$.

\section{Pembuatan CMC-Na}

CMC-Na $1 \%$ dibuat dengan cara menimbang sebanyak 1 gram kemudian dikembangkan dalam air panas sebanyak $20 \mathrm{~mL}$. Setelah itu di larutkan menggunakan aquadest hingga $100 \mathrm{~mL}$. CMC-Na dibuat dalam kondisi baru setiap kali akan menggunakan.

\section{Pembuatan suspensi fraksi etil asetat ekstrak etanol buah kemukus}

Suspensi FEAEE buah kemukus dibuat dengan kadar 0,315; 0,63; 1,26; 2,52 \% masing-masing sebanyak $10 \mathrm{~mL}$. Kemudian FEAEE buah kemukus disuspensikan dengan CMC-Na 1\% sampai dengan volume akhir $10 \mathrm{~mL}$.

\section{Penyiapan hewan uji}

Sebanyak 25 hewan uji dibagi dalam 5 kelompok. Kelompok 1 sebagai kontrol negatif, diberikan CMC-Na, sementara kelompok 2, 3, 4 dan 5 adalah kelompok perlakuan pemberian FEAEE buah kemukus dengan dosis masing-masing 63, 126, 252, dan $504 \mathrm{mg} / \mathrm{kgBB}$.

\section{Pengukuran skor memori}

Data yang diperoleh pada uji aktivitas peningkatan daya ingat adalah frekuensi mencit memasuki lengan platform dengan benar (A) dan frekuensi mencit memasuki lengan platform yang salah (B). Skor memori tiap mencit pada semua kelompok perlakuan dihitung dengan rumus berikut ini (Richter dkk., 2013).

$$
\text { Skor memori }=\frac{A-B}{A+B}
$$

\section{Analisis Data}

Data hasil skor memori diuji menggunakan distribusi normalitas, Shapiro Wilk (p>0.05). Perbedaan pada skor memori sebelum dan setelah perlakukan dianalisis menggunakan uji $\mathrm{t}$ berpasangan. FEAEE buah kemukus dinyatakan mempunyai aktivitas sebagai peningkat daya ingat bila skor memori sesudah perlakuan memiliki nilai lebih besar secara bermakna dibandingkan dengan sebelum perlakuan.

\section{HASIL DAN PEMBAHASAN}


Penelitian ini menggunakan buah kemukus yang didapatkan dari Pengembangan Tanaman Obat dan Obat Tradisional (B2P2POOT) Tawangmangu, Karanganyar, Jawa Tengah. Ekstraksi buah kemukus secara maserasi dengan etanol 70\%. Fraksinasi ekstrak etanol buah kemukus dengan etil asetat dilakukan pengulangan sebanyak 3 kali. Fase etil asetat yang terkumpul selama proses fraksinasi sebanyak 1.65 L. Kemudian fase etil asetat diuapkan dengan rotary evaporator dengansuhu $55^{\circ} \mathrm{C}$.

Buah kemukus mengandung flavonoid. Flavonoid merupakan metabolit sekunder yang dapat terurai oleh pemanasan (Riyanto, 1990). Penggunaan rotary evaporator menghindarkan penguapan etil asetat pada suhu yang tinggi karena penguapannya tidak hanya menggunakan panas, namun juga memanfaatkan pengurangan tekanan. Pengurangan tekanan akan menurunkan titik didih etil asetat, sehingga meningkatkan kecepatan penguapan (BPOM RI, 2013).Hasil penguapan fase etil asetat pada proses fraksinasi ekstrak etanol buah kemukus adalah FEAEE buah kemukus. Ekstrak etanol buah kemukus sebanyak $50 \mathrm{~g}$ difraksinasi menghasilkan fraksi sebanyak 14,4 g. Rendemen fraksi dalam penelitian ini sebesar $28,8 \%$.

Prosedur pengujian aktivitas daya ingat mengacu pada Wenk (2004) dengan modifikasi. Metode uji yang digunakan untuk uji aktivitas peningkat daya ingat pada penelitian adalah radial arm maze (RAM). Prinsip metode dengan mengukur skor memori terhadap frekuensi mencit yang memasuki platform secara benar atau salah. Mencit dikatakan memiliki daya ingat tinggi jika frekuensi melewati platform dengan benar lebih banyak dibandingkan frekuensi kesalahan melewati platform. Semakin tinggi daya ingat mencit, maka skor memorinya juga semakin tinggi. Secara teoritis, senyawa yang dapat meningkatkan daya ingat yang diberikan pada mencit akan menghasilkan skor memori yang lebih tinggi secara bermakna dibandingkan sebelum diberikan senyawa tersebut. Rangkuman skor memori tiap kelompok mulai hari pertama hingga hari ke-21 dirata-rata. Perbedaan metode RAM dengan metode MorrizWater Maze (MWM) adalah pada metode MWM penggunaan motivasi penyelamatan diri untuk belajar dan mengingat, sedangkan pada metode radial arm maze menggunakan pencarian makanan sebagai motivasinya. Hewan uji lebih mudah menyerah ketika diuji pada Morriswater maze dibandingkan pada radial arm maze ( Vorhees dan Williams, 2014; Wenk, 2004; Hodges, 1996).

Mencit dipuasakan selama 12 jam sebelum dilakukan fase adaptasi. Adaptasi dilakukan selama 3 hari dengan memberikan pelet pada ujung lengan platform/labirin dan di pintu masuk lengan platform/labirin. Fase latihan dilakukan satu kali sehari, setiap hari selama 12 hari dengan cara meletakkan pellet pada ujung lengan labirin yang tidak terlihat oleh mencit dari pusat. Selanjutnya adalah fase uji, Mencit pada tiap kelompok 1 diberi larutan CMC-Na 1\% sebanyak $17,5 \mathrm{~mL} / \mathrm{kgBB}$. Mencit pada kelompok 2, 3, 4, dan 5 diberi fraksi etil asetat ekstrak etanol buah kemukus dengan dosis berturut-turut 63, 126, 252, dan $504 \mathrm{mg} / \mathrm{kgBB}$. Pengamatan meliputi frekuensi mencit memasuki lengan labirin dengan benar dan frekuensi mencit salah memasuki lengan platform/labirin. Pengamatan pada hari ke-1 menghasilkan data sebelum perlakuan (pretest). Sementara pengamatan pada hari ke-21 pemberian larutan uji menghasilkan data sesudah perlakuan (post-test). Pengukuran skor memori pada mencit jantan galur Balb/c dilakukan setelah pemberian FEAEE selama 21 hari. Data yang diperoleh pada uji aktivitas peningkatan daya ingat adalah frekuensi mencit memasuki lengan platform dengan benar (A) dan frekuensi mencit memasuki lengan platform yang salah (B). Uji dinyatakan selesai bila mencit telah memasuki semua lengan atau 10 menit telah berlalu. Hasil pengamatan yang perlu dicatat adalah (A) jumlah pilihan yang benar dalam memasuki setiap lengan di setiap sesi (memasuki lengan yang belum pernah dikunjungi sebelumnya pada sesi tersebut), dan (B) jumlah kesalahan dalam setiap sesi (memasuki lengan yang telah dikunjungi sebelumnya dan/atau tidak memasuki satu atau lebih lengan dalam setiap sesi dihitung sebagai kesalahan).

Gambar 1 adalah kurva rata-rata skor memori tiap kelompok mulai hari pertama hingga hari ke-21 pengujian. Pada umumnya semua kelompok perlakuan mengalami peningkatan skor memori selama diberikan larutan uji, kecuali pada kelompok 1 yaitu kelompok kontrol negatif yang hanya diberikan larutan CMC-Na 1\% sebagai bahan pembawa. Kurva rata-rata skor memori pada mencit kelompok negatif mengalami kenaikan dan penurunan selama fase pengujian, namun pada akhir pengujian skor memorinya mengalami kenaikan. 


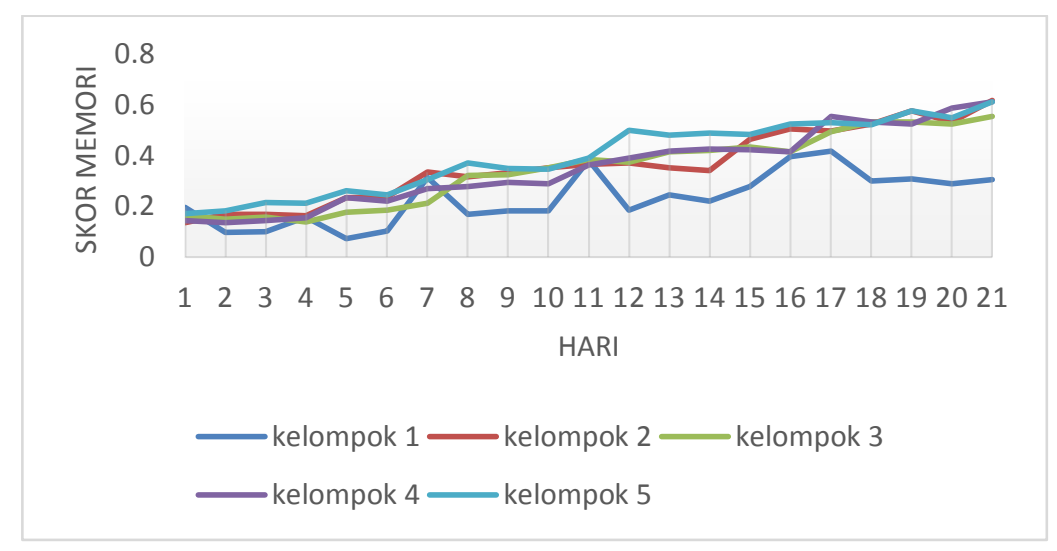

Gambar 1. Kurva rata-rata skor memori setiap kelompok

\section{Keterangan :}

Kelompok 1 : kelompok kontrol negatif dengan CMC-Na $1 \%$ sebanyak 17,5 mL/kgBB

Kelompok 2 : kelompok perlakuan yang diberi FEAEE buah kemukus dosis $63 \mathrm{mg} / \mathrm{kgBB}$

Kelompok 3 : kelompok perlakuan yang diberi FEAEE buah kemukus dosis $126 \mathrm{mg} / \mathrm{kgBB}$

Kelompok 4 : kelompok perlakuan yang diberi FEAEE buah kemukus dosis $252 \mathrm{mg} / \mathrm{kgBB}$

Kelompok 5 : kelompok perlakuan yang diberi FEAEE buah kemukus dosis $504 \mathrm{mg} / \mathrm{kgBB}$

FEAEE : fraksi etil asetat ekstrak etanol

Gambar 2 menunjukkan semua kelompok perlakuan mengalami kenaikan skor memori. Rata-rata skor memori kelompok kontrol negatif sebelum diberikan larutan CMC-Na 1\% sebesar 0,196, dan setelah diberikan larutan CMC-Na skor memori mengalami kenaikan menjadi 0,304. Hasil analisa statistik dengan uji t-berpasangan menunjukkan kenaikan tersebut tidak bermakna (p>0,05). Larutan CMC-Na 1\% sebagai larutan pembawa FEAEE buah kemukus tidak mempunyai aktivitas sebagai peningkat daya ingat.

Kelompok 2 dan 4 mengalami kenaikan skor memori setelah diberi FEAEE buah kemukus selama 21 hari. Signifikansi hasil uji t berpasangan pada kedua kelompok tersebut berturut-turut sebesar 0,025 dan 0,043 ( $<<0,05)$. Berdasarkan nilai signifikansi tersebut dapat dinyatakan bahwa terjadi kenaikan skor memori yang bermakna setelah pemberian FEAEE buah kemukus. Pemberian FEAEE buah kemukus dosis 63 dan $252 \mathrm{mg} / \mathrm{kgBB}$ dapat meningkatkan daya ingat mencit.

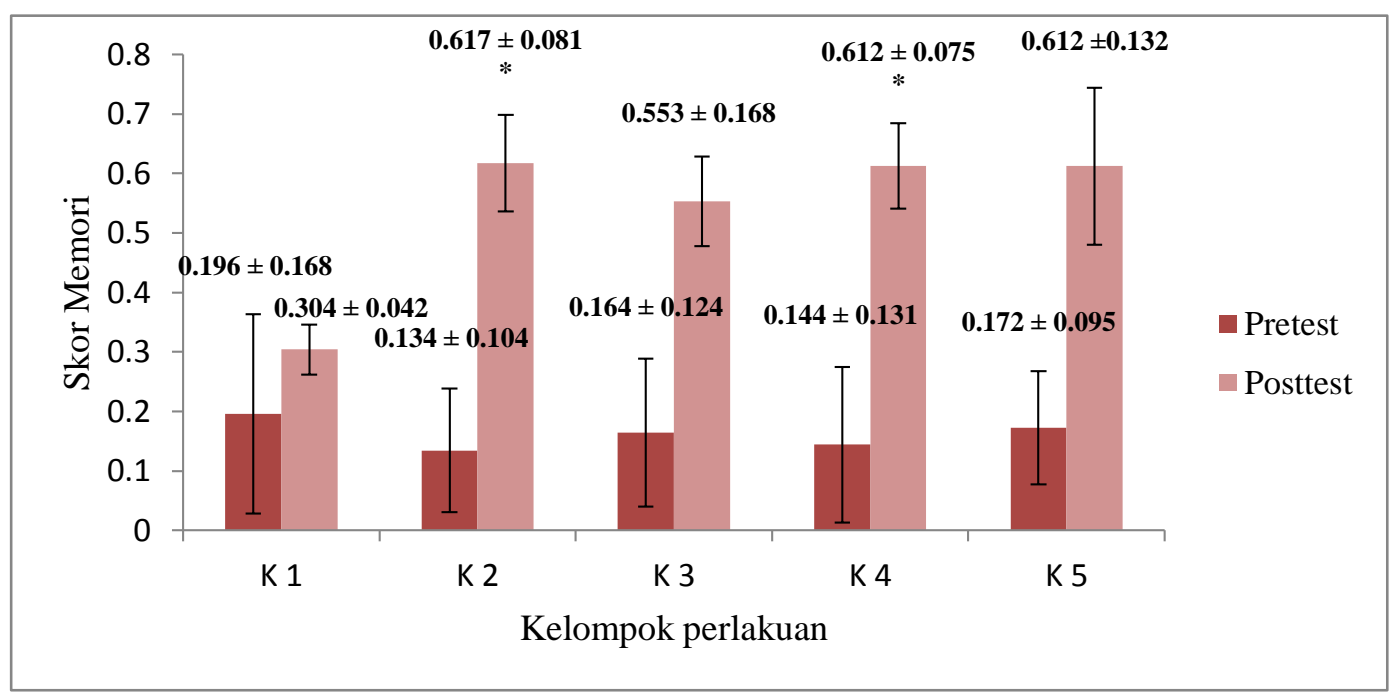

Gambar 2. Diagram skor memori sebelum dan setelah diberikan perlakuan *: berbeda bermakna dibandingkan sebelum perlakuan 
Hasil penelitian menunjukkan semua kelompok perlakuan mengalami peningkatan skor memori selama diberikan perlakuan FEAEE buah kemukus pada berbagai konsentrasi. Pada kelompok kontrol negatif yang diberikan CMC-Na $1 \%$ skor memori tidak mengalami peningkatan secara signifikan. Kurva rata-rata skor memori pada mencit kelompok kontrol negatif mengalami kenaikan dan penurunan selama fase pengujian, namun pada akhir fase pengujian skor memori mencit kelompok ini mengalami kenaikan. Rata-rata skor memori pada kelompok kontrol negatif sebelum diberikan CMC-Na 1\% sebesar 0,196, dan mengalami kenaikan skor memori menjadi 0,304 . Hasil tersebut diuji menggunakan uji t-berpasangan dan menunjukkan kenaikan tidak bermakna ( $>0,05)$. Sehingga dapat dikatakan bahwa larutan CMC-Na 1\% tidak memiliki aktivitas sebagai peningkat daya ingat.

Pada kelompok perlakuan 2 dan 4, dengan pemberian FEAEE buah kemukus secara berturutturut, $63 \mathrm{mg} / \mathrm{kg}$ BB dan $252 \mathrm{mg} / \mathrm{kgBB}$ mengalami kenaikan skor memori dengan signifikansi hasil uji 0,025 dan 0,043 ( $\mathrm{p}<0,05)$. Dengan hasil tersebut menyatakan pemberian FEAEE buah kemukus dosis 63 dan $252 \mathrm{mg} / \mathrm{kgBB}$ dapat meningkatkan daya ingat mencit. Pada kelompok 3 dan 5, pemberian FEAEE buah kemukus dosis $126 \mathrm{mg} / \mathrm{kgBB}$ dan $504 \mathrm{mg} / \mathrm{kgBB}$ menunjukkan bahwa FEAEE buah kemukus tidak mempunyai aktivitas sebagai peningkat daya ingat.

\section{KESIMPULAN}

FEAEE buah kemukus memiliki efek sebagai peningkat daya ingat mencit pada dosis 63 dan $252 \mathrm{mg} / \mathrm{kgBB}$.

\section{SARAN}

a. Perlu dilakukan identifikasi awal kemampuan mencit sehingga dapat diketahui kemampuan mengingat/daya memori masing-masing mencit.

b. Perlu ditambahkan kelompok kontrol positif dalam penelitian yang serupa dengan penelitian ini.

\section{DAFTAR PUSTAKA}

BPOM RI, 2013, Pedoman Teknologi Formulasi Sediaan Berbasis Ekstrak, Direktorat Obat Asli Indonesia, Badan Pengawas Obat dan Makanan Republik Indonesia, Jakarta, 12 - 14

Chalfonte, B. L., Verfaellie, M., Johnson, M. K., \& Reiss, L., 1996, Spatial location memory in amnesia: Binding item and location information under incidental and intentional encoding conditions. Memory, 4, 591-614. doi: 10.1080/ 741940998

Ganong, W.F., 2002, Buku Ajar Fisiologi Kedokteran, diterjemahkan oleh Djauhari Widjajakusumah, Dewi Irawati, Minarma Siagian, Dangsima Moeloek, Brahm U. Pandit, Edisi 20, Penerbit Buku Kedokteran EGC, Jakarta, 258 - 263

Guyton, A. C. \& Hall, J. E. (2001). Buku ajar fisiologi kedokteran. Jakarta: EGC

Hodges, H., 1996, Maze Procedure; The Radial Arm and Water Maze Compared, Brain Research Cognitive Brain Research, (3)3-4, 167-181

Kida, S., 2012, A Functional Role for CREB as A Positive Regulator of Memory Formation and LTP, Experimental Neurobiology, 21(4), 136 - 140

Macready, A.L., Kennedy, O.B., Ellis, J.A., Williams, C.M., Spencer, J.P.E., and Butler, L.T., 2009, Flavonoids and Cognitive Function: A Review of Human Randomized Controlled Trial Studies and Recommendation for Future Studies, Genes and Nutrition, 4, 227 - 242

National Institute of Aging, 2010, Understanding Memory Loss, US Departement of Health and Human Services, 9

Pham-Huy, L.A., He, H., and Pham-Huy, C., 2008, Free Radicals, Antioxidants in Disease and Health, International Journal of Biomedical Science, 4(2), 89 - 96

Pinel, J. P. J. (2009). Stres dan kesehatan dalam: Biopsikologi edisi ke-7. Yogyakarta: Pustaka Pelajar.

Prince, M., Albanese, E., Guerchet, M., and Prina, M., 2014, Nutrition And Dementia, Alzheimer's Disease International, London 
Prichett, K, and Mulder, G.B., 2003, T, Radial Arm, and Barnes Mazes, Contemporary Topics, 42 (3), $53-55$

Richter, S.H., Zeuch, B., Lankisch, K., Gass, P., Durstewitz, D., and Vollmayr, B., 2013, Where Have I Been? Where Should I Go? Spatial Working Memory on A Radial Arm Maze in A Rat Model of Depression, Plos One, 8(4), 1 - 10

Riyanto, S., 1990, Flavonoid, dalam Mursyidi, A., (Ed), Analisis Metabolit Sekunder, Proyek Pengembangan Pusat Fasilitas Bersama Antar Universitas (Bank Dunia XVII) - PAU Bioteknologi Universitas Gadjah Mada, Yogyakarta, 171 - 175

Sherwood, L., 2013, Human Physiology from Cells to System, $8^{\text {th }}$ Edition, Brooks/Cole Cengage Learning, Belmont, $73-75$

Vorhees, C.V. and Williams, M.T., 2014, Assessing Spatial Learning and Memory in Rodent, Institute of Laboratory Animal Resource Journal, 55(2), 310 - 332

Wenk,G.L.,2004, Assessment of Spatial Memory Using the Radial Arm Maze and Morris Water Maze,in Gerfen C.,Holmes,A.,Sibley D.,Skolnick, P.,Wray,S., (Eds.), Current Protocols in Neuroscience, Wiley \& Sons,Inc., NewYork, 8.5A.1 - 8.5A.12 